\title{
RETTEN TIL TAVSHED, PLIGTEN TIL TALE
}

Om familiehemmeligheder og statslig erindringspolitik

\author{
KARIN LÜTZEN
}

I 2009 udgav jeg bogen Mors hemmelighed. På sporet af en jødisk indvandrerhistorie. Den omhandler, hvorledes jeg efter min franske mors død fandt ud af, at hun var barn af rumænske jøder, der var indvandret til Paris omkring år 1900. I bogen tager jeg læserne med på mit opklaringsarbejde for at finde dokumenter og nulevende slægtninge, og hele denne familiehistorie sætter jeg ind i en større europæisk sammenhæng.

Tavshed er det modsatte af tale, men tavshed er også et udtryk for glemsel. Når der ikke bliver talt om noget, går det i glemmebogen. I Mors hemmelighed reflekterer jeg over private menneskers ret til at glemme, til ikke at tale om noget, de ønsker at lægge bag sig. Men samtidig ser jeg på staters pligt til at huske, og jeg undersøger hele den erindringspolitik, som er udviklet vedrørende Holocaust. Min mor ønskede ikke at tale om sin jødiske baggrund, hun holdt den endog hemmelig, hvorimod den franske republik i de seneste årtier er blevet pålagt en pligt til at mindes og tale offentligt om de deporterede jøder.

\section{Mors hemmelighed}

Min mor er født i 1923 på Montmartre i Paris og var enebarn. I 1935 flyttede hun med sine forældre til en by i Midtfrankrig, og efter at Paris var blevet befriet i 1944, begyndte hun at studere på Sorbonne Universitet. I 1947 rejste hun med en gruppe studerende til Danmark, hvor de var inviteret til at tilbringe sommeren hos danske familier, hun mødte min far, og året efter giftede de sig. Det er kort fortalt hendes historie, og det er også stort set, hvad mine søskende og jeg hørte om, da vi var små. Hendes mor døde, før vi blev født, men hendes far kendte vi og besøgte hver sommer i Frankrig. De havde ingen slægtninge, hvad vi åbenbart ikke undrede os over, men min mor havde det, man kan kalde „en 
tilvalgt familie“, altså mennesker, der stod hende nær, og som hun havde mødt i sin barndom og ungdom. Både min mor og min morfar var overmåde stolte over at være franske, og min mor fremhævede altid det fremragende ved den sekulære franske republik.

Nogle år efter hendes død ville jeg for sjov finde ud af, om hendes forældre mon også var født i Paris, eller om de var fra landet. Stor var min overraskelse derfor, da jeg fik fremskaffet min mors fødselsattest og deraf kunne forstå, at hendes forældre var født i Rumænien. Vidnerne til attesten havde påfaldende jødiske navne og erhverv (skrædder og buntmager), og det dæmrede for mig, at de måske var jødiske indvandrere, der var flygtet fra jødeforfølgelse.

Jeg gik derfor i gang med et større slægtsforskningsarbejde og fandt ud af ikke blot, at begge mine morforældre var jøder, men også at de var ældste børn af en stor søskendeflok. Min mor havde altså haft et utal af onkler og tanter og fætre og kusiner uden nogensinde at have talt om det. Mine morforældre var ankommet til Paris som børn, havde gået i fransk skole og var samtidig en del af det østjødiske indvandrermiljø, hvor de må have mødt hinanden.

Jeg fandt også ud af, at alle i slægten - naturligvis - havde arbejdet med de såkaldte jødiske erhverv i beklædningsindustrien, og at min morfar var uddannet skrædder, men efter sit giftermål begyndte at arbejde som handelsrejsende $\mathrm{i}$ klædestoffer - hvad der også var hans erhverv i min barndom.

Den mest tragiske opdagelse var dog, at jødeforfølgelserne under Anden Verdenskrig også var gået ud over min mors slægt. Jeg vil nok aldrig kunne finde ud af, hvordan min mor og hendes forældre undgik at blive forfulgt. De forlod Paris før besættelsen og ankom til den mindre by sydligere i Frankrig som en nydelig parisisk familie, alle tre talte perfekt fransk, familienavnet var ikke påfaldende jødisk, de holdt ingen jødiske traditioner og omgikkes ikke andre jøder. Måske havde de allerede da påbegyndt deres assimilationsproces ind i det franske samfund, og ingen tænkte derfor på at angive dem som jøder.

Men så heldige var alle deres slægtninge ikke. En af min morfars brødre var allerede i 1942 blevet sendt til Auschwitz sammen med sin kone og to små børn. Ingen af dem vendte tilbage, og min mor mistede således en farbror, en tante, en fætter og en kusine - og måske har dette tab været så traumatisk, at hun aldrig har villet tale om sin baggrund. Men igennem min slægtsforskning fandt jeg også ud af, at der i hver eneste gren af min mors indvandrede slægt var et medlem, som var blevet deporteret. Eller de havde gennemlevet krigsårene som flygtninge, eller de havde ladet deres børn døbe i den katolske kirke i håb om at redde dem. Alle i min mors slægt har således været berørt af la Shoah - af jødeudryddelsen.

Gennem min slægtsforskning lykkedes det mig at opspore endnu levende slægtninge, som kunne huske min mor og hendes forældre, og som kunne 
fortælle mig mange historier. Jeg kredsede naturligvis hele tiden om tavsheden, om spørgsmålet om, hvorfor min mor aldrig havde fortalt os om sin baggrund og om sine utallige slægtninge.

Alt dette har jeg skrevet om i min bog, og jeg har også undersøgt den jødiske indvandrings historie og sat den lille historie ind i en større sammenhæng. Men hvad gør denne historie interessant for andre end mine søskende og mig? Det er, at den omhandler en familiehemmelighed, som helt tilfældigt bliver afsløret. I mange familier er der hemmeligheder, og nogle kan ligge som en lammende skygge over familielivet og dække over: at barnet er adopteret, at far var stikker under besættelsen, at mor har været gift før, at bedstefar begik underslæb og dernæst begik selvmord - og så fremdeles.

Det interessante er at undersøge, hvad hemmeligheden går ud på, hvilke bevæggrunde der har været for at holde sandheden skjult, hvad fordelen kunne være, men også de tab, der er forbundet med det. Og hvad betyder det for de „,narrede“ familiemedlemmer, når de opdager sandheden? Bliver det en lettelse eller en byrde? Når den virkelige sandhed hemmeligholdes, må der nødvendigvis konstrueres en anden sandhed, som kan træde i stedet for den hemmeligholdte sandhed. Hvad er det så for en historie, der bliver fortalt? Hvilken strategi bliver valgt for at vige uden om det minerede område, hvor hemmeligheden ligger begravet? Og kan den nye konstruerede sandhed ende med at blive så overbevisende, at den træder i stedet for den hemmeligholdte sandhed?

Den engelske sociolog Carol Smart har beskæftiget sig med familiehemmeligheder, og hun anvender begreberne ,narratives of avoidance“ og ,,active notknowing“ (Smart 2011:549). Hendes antagelse er, at i familier med hemmeligheder lærer børnene, hvad de ikke skal spørge om og derfor ikke vide noget om, ligesom de godtager, at de fortællinger, de præsenteres for, går uden om den varme grød. De aner, at der er noget, „man ikke taler om“, noget, der hersker tavshed om, men hvad det er, ved de ikke.

Det er også denne ,undgåelsens fortælling“, der var på spil i min familie. Her nogle år senere, hvor jeg har afdækket min mors familiehistorie, kan jeg se, at det næsten var, som om min mor havde bedøvet mine søskende og mig med et lammende hukommelsestabsgiftstof det sted i vores hjerner, som skulle have med hendes familiehistorie at gøre. Eller mere psykologisk kan man også sige, at vi har arvet hendes fortrængning. Alt vedrørende hendes familiehistorie var et mineret område og derfor noget, vi gik i en stor bue uden om. Vi godtog, at hun ingen slægtninge havde ud over sine forældre og undrede os ikke, ligesom vi aldrig nogensinde fandt på at spørge til hendes forældres familiebaggrund. Vi fornemmede, at det var noget, vi skulle undgå, og jeg tror ikke engang, at vi i vores stille sind undrede os. 
Min mor og hendes far fortalte aldrig en løgnehistorie, men de undlod at fortælle den historie, som jeg efterhånden fik afdækket. Gennem fortielse konstruerede min mor sin familiehistorie, og mine søskende og jeg puslede de få brikker, vi havde til vores rådighed, sammen til et helt billede. Ved at godtage, at der var noget, der ikke skulle tales om, hjalp vi - uden at være os det bevidst - min mor med at holde på sin hemmelighed.

\section{Mors jødiske hemmelighed}

Der er tre bestanddele i min mors hemmelighed: at hun var jøde, at hun var andengenerationsindvandrer, og at hun havde en stor slægt. Det er oplysninger, som var ukendte for mig, og som jeg derfor tillægger en enorm stor betydning, ja, nærmest en omvæltende betydning for forståelsen af min mor. Men måske er pointen, at disse tre bestanddele har været en plage for min mor, og at hun derfor har skabt sig en fortælling om, at det er ligegyldigt, hvad man kommer af, det vigtigste er, hvad man bliver til.

Eller måske overfortolker jeg, og måske har det ikke været en plage for hende at være jødisk andengenerationsindvandrer med en stor slægt, det har bare været en baggrund, hun voksede fra, og derfor blegnede mindet om det med tiden. Men hvis den baggrund var ligegyldig, kunne hun jo netop have talt om den for at fortælle, hvor ligegyldig den var. Når hun så omhyggeligt undgik at omtale den, er det måske, fordi den var overordentlig betydningsfuld som en byrde.

Jeg vil aldrig kunne få et klart svar på, hvilke bevæggrunde min mor og sikkert også hendes forældre har haft for at undlade at fortælle om denne baggrund. Jeg vil kun kunne stykke et billede sammen af alle de fortællinger, deres slægtninge kan fortælle mig. Disse slægtninge lægger alle vægten et forskelligt sted. Der er dog ét træk, der går igen i alle fortællingerne, og det er, at min mors forældre havde ambitioner om at bevæge sig ud af den østjødiske arbejderklasse og ind i den franske middelstand. De ville assimileres, de ville være rigtig franske, og det kunne kun gå for langsomt. Deres slægtninge, som trivedes i det store østjødiske indvandrernetværk i Paris, følte sig skubbet til side og blev sårede over, at deres livsform ikke blev anerkendt af min mors forældre.

Da jeg spurgte en af min mors kusiner, om hun kunne hjælpe mig med at afdække gåden om, hvorfor min mor og min morfar havde været tavse om deres jødiske baggrund, sagde hun: ,Jeg tror, jeg har forklaringen. Deres morfar (vi var endnu Des) ville ikke være jøde.“ Hun sagde, at han gav udtryk for, at han ikke brød sig om fattige jøder, og syntes, at de var flæbende, tiggende og ville have alting billigt. 
Det lyder jo næsten som en antisemitisk floskel, men det kan tænkes, at han havde indoptaget antisemitiske forestillinger. Selv om min morfar var runden af en beskeden jødisk herkomst, ville han ikke blive i den. „Deres morfar“, sagde hun, ,var ikke ligesom resten af familien, men mere fin på den og følte sig hævet over de andre. Han var stræbsom og ville træde ind i middelklassen - og det lykkedes også.“

Hun fortalte, at min morfar altid var velklædt (i modsætning til hendes egen bødkerfar, som ofte var iklædt snusket arbejdstøj), altid med slips, selv nogle gange i strandkanten.

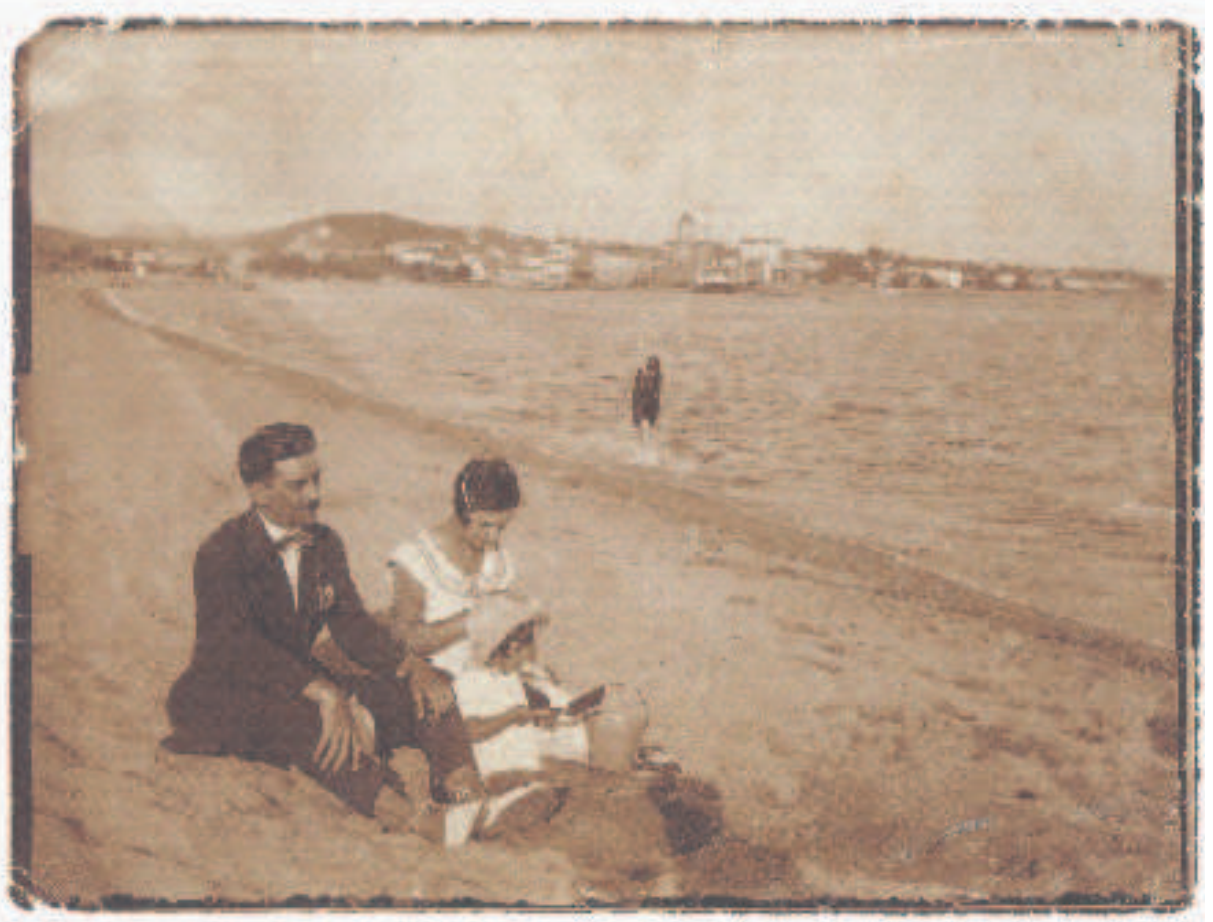

Min mor med sine forældre på ferie i juli 1925 i Saint-Raphaël ved Middelhavet

Han var høj i modsætning til sine lavere slægtninge, elegant, velformuleret, talte fuldstændig korrekt fransk og rettede på sine slægtninges grammatik og udtale. Han var kort sagt beundringsværdig, men en plage for sine omgivelser, som blev nervøse i hans selskab. Min morfar havde afskåret sig fra fællesskabet for at kunne kravle op ad den sociale rangstige. Han lagde afstand til det jødiske, som for ham måske var ensbetydende med små kår og frivilligt eksil i majoritetssamfundet. For hans søskende og deres mænd og koner var det jødiske indvandrermiljø derimod indbegrebet af et trygt fællesskab, hvor man kunne føle sig hjemme. 
Man fødes ikke som franskmand, man bliver det - dette kunne være mine morforældres omskrivning af det berømte citat af Simone de Beauvoir: Man fødes ikke som kvinde, man bliver det. En sådan opfattelse anerkender, at det kvindelige ikke er en essens, men noget, man tilegner sig ved at fornemme de kulturelle signaler i sin samtid. En sådan opfattelse åbner også for muligheden af, at man kan skabe sin egen identitet, hvis man ikke er tilfreds med den, som er én givet.

Det skal ikke forstås sådan, at man hver morgen ser sig selv i spejlet og spørger, om man i dag skal være kineser, homoseksuel eller indvandrer. Det er ikke så nemt som at vælge et par sko. Men det er en anerkendelse af, at det moderne samfund, som netop er kendetegnet ved, at man har fjernet sig fra det gamle standssamfund, hvor en skomager skulle blive ved sin læst, giver mulighed for en ny start på livet.

At udvandre er i sig selv en mulighed for at begynde på en frisk. De østjødiske udvandrere fjernede sig fra et samfund, der tilskrev jøder bestemte egenskaber og derfor også begrænsede deres udfoldelsesmuligheder. Når de pakkede deres ransel og gik mod nye horisonter, åbnede de samtidig for muligheden af at kunne leve et andet liv.

Den nazistiske forfølgelse af Europas jøder, ofte med velvillig bistand af myndighederne i de besatte lande, fik forskellig betydning for jøder. Nogle blev dermed bevidst om deres jødiskhed og opdagede sig selv som jøde, en erkendelse, som ikke forlod dem efter krigen. For andre kan denne helt igennem hæslige tid have haft den følge, at de ville skære den del af deres identitet væk, som var det en pestbyld, der for altid satte dem uden for det gode selskab.

Det kan meget vel tænkes, at det har været den konklusion, min mor og hendes forældre kom frem til. Det kan også tænkes, at det jødiske efterhånden ikke har været forbundet med andet end små kår, forskelsbehandling og forfølgelse, og at det bedste ville være at glemme alt om, at det havde noget med én selv at gøre.

Så vidt jeg har kunnet finde ud af, er det i hele slægten udelukkende min mor og hendes forældre, som har lagt afstand til deres jødiske identitet, mens resten af slægten har valgt andre strategier. Det at fornægte sin jødiske baggrund går imod den jødiske tradition. Når den jødiske nation altid har været et mindretal i de stater, hvor de har bosat sig, har det været dem magtpåliggende, at de ikke assimilerede sig ihjel. Jo flere der gled ind i det store samfund gennem blandede ægteskaber og konversion, desto færre jøder var der til at føre den jødiske nation videre.

Dette at huske og at mindes er en vigtig del af den jødiske kultur, som min mor og hendes forældre har ladet hånt om. De var overlevere, men de var også en slags landssvigere, der svigtede deres folk. Om den slags mennesker lader Elie Wiesel sin hovedperson Elhanan Rosenbaum sige på sidste side i romanen 
L'oublié - den glemte - fra 1989: „En frafalden jøde bringer skam over alle dem, som er gået forud. Sig til din søn, at han ikke må bringe skam over mig. En frafalden jøde gør ikke andet end at vælge løgnen. Hvis han lyver for sig selv, hvordan vil han kunne vise sig sand sammen med andre?"“

Det er en forfærdelig dom at fælde over andre mennesker, som kan have taget denne beslutning efter svære overvejelser. Men har Elie Wiesel ret? Er den jødiske identitet så meget af en sand essens, at fornægtelsen af den og tavsheden om den vil medføre en usand personlighed? Det ville min mor sikkert ikke give ham ret i, hvis hendes afstandstagen da ikke har været så virkningsfuld, at hun slet ikke mente, det angik hende.

Det kan selvfølgelig også tænkes, at det overhovedet ikke har været en belastning at fjerne sig fra den jødiske baggrund. Det er jo muligt, at det for min mor var en lettelse at få en ny begyndelse, og at hun hver dag følte sig heldig, fordi hun nu levede i et ganske andet miljø i et ganske andet land.

Hele dette ræsonnement om hemmeligholdelse og tavshed lægger vægt på, at det er positivt og vigtigt at huske og mindes. Der er i de sidste år opstået en pligt til at mindes, en „devoir de mémoire“, som det hedder på fransk, og det omhandler naturligvis især den nationale historie. Men har enkeltpersoner også pligt til at huske på deres egen fortid og at tale om den? Det er vel værd at diskutere, og måske kan man lige så vel hævde retten til at glemme og fortrænge, for noget har måske bedst af at blive glemt og fortiet. Evnen til at kunne fortrænge kan være en vigtig overlevelsesstrategi. Samtidig kan det diskuteres, om forældre egentlig har pligt til at fortælle alt om deres egen fortid. Måske bør vi respektere de valg, vi foretager med hensyn til at huske eller at glemme - til at tale eller være tavse.

\section{Jøder i Frankrig}

Pligten til at huske, og dermed til at tale, at bryde tavsheden, er blevet et påbud for stater og historieskrivning i de seneste årtier. Det er alt lige fra Holocaust og fabrikkers slavearbejdere under Anden Verdenskrig til tvangsforflytning af grønlandske børn i 1950'erne til slavehandelen for flere hundrede år siden. Alt skal frem i lyset, alt skal der tages ansvar for og helst også undskyldes for.

Min mors tavshed om sin jødiske baggrund står i kontrast til det krav, der i de senere årtier har været fremsat i Frankrig om at huske på ofrene for jødeforfølgelsen. Lige efter krigen var det især de heltemodige modstandskæmpere, som blev erindret, og jøderne blev ikke fremdraget som en særlig gruppe. For at forstå denne strategi er det vigtigt at kende til den franske republiks grundlæggende idéer. 


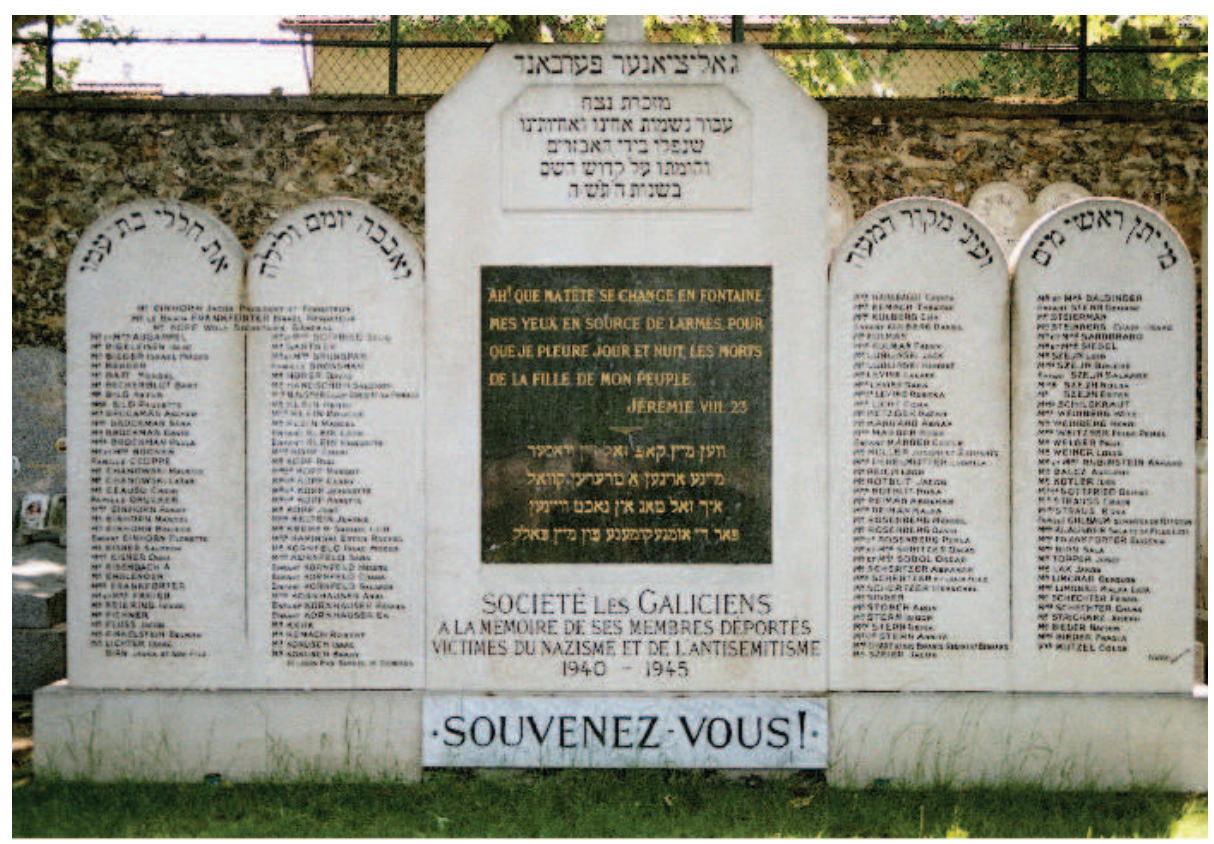

Efter krigen oprettede jødiske foreninger selv mindesten på begravelsespladserne for deres deporterede medlemmer, som her den galiciske forening, der anførte navnene på alle de deporterede „ofre for nazisme og antisemitisme”. Listen fortsætter på bagsiden af stenen, hvilket den lille pil nederst i højre hjørne viser.

En af de væsentlige idéer var, at alle indbyggere i Frankrig, hvad enten de havde boet $i$ landet i generationer eller lige var indvandret, skulle assimileres ind i den franske nation. Allerede i revolutionsåret 1789 blev princippet om ,la nation une et indivisible“" slået fast, altså at nationen var én og udelelig, et princip, der stadig er gældende i Frankrig. Nationen blev ikke, som i mere nationalromantiske stater, opfattet som en etnisk enhed, men derimod som en enhed af borgere, der tilsluttede sig republikkens idéer. Derfor ville indvandrere også kunne blive „franske“, når blot de respekterede disse idéer, lærte sig fransk, overholdt landets love og aftjente deres værnepligt (Safran 1991, 1997).

Hvis nationen skulle være én og udelelig, kunne man ikke tillade en stat i staten eller det, som nu kaldes ,parallelsamfund“. Under revolutionen blev alle lav og korporationer derfor ophævet, og enhver borger i det franske samfund fik en direkte forbindelse til nationen. Frankrig var den første stat i Europa, som i 1791 emanciperede de omtrent 40.000 jøder, der boede i landet. Under drøftelsen i den grundlovgivende forsamling af spørgsmålet om, hvem der skulle have borgerskab, havde grev de Clermont-Tonnerre sagt: „Il faut tout refuser aux Juifs comme nation, et accorder tout aux Juifs comme individus." Med andre ord: Jøder skulle 
nægtes alt som nation, men som individer skulle jøder gives alle rettigheder. I republikken anerkendes jødedom derfor udelukkende som en religion på linje med andre trossamfund (Winock 2004).

Med disse republikanske idéer kan staten som sagt ikke bestå af fællesskaber, men udelukkende af individer, der alle tilslutter sig republikkens principper. Derfor er „multikulturalisme“ uforenelig med grundlaget for den franske nation. Religiøse, etniske og regionale mindretal kan dyrke deres særegenhed i det private liv og som en kultur, der er underordnet den franske nation, men den kultur kan ikke begynde at konkurrere med republikkens grundlæggende idéer.

Under besættelsen blev disse idéer væltet over ende. Frankrig blev besat af Tyskland, og regeringsmagten blev overdraget til den 84-årige marskal Pétain, den store helt fra Første Verdenskrig. Han dannede regering i kurbyen Vichy, og deraf kommer navnet på det styre, han stod i spidsen for under den tyske besættelse - et overordentligt samarbejdsvilligt styre. Hans nationale revolution, som den blev kaldt, smed republikkens slagord om frihed, lighed og broderskab på møddingen og erstattede dem med treenigheden: arbejde, familie, fædreland de sædvanlige konservative dyder. Det var ikke længere La République française (den franske republik), der regerede landet, men derimod L'État français (den franske stat). Denne vigtige skelnen blev understreget i årene efter befrielsen og medførte, at der sænkede sig en tavshed over kendskabet til denne periode (Rousso 2001).

Det var også den franske stat, der allerede i 1940 udstedte jødelove, der gav jøderne i Frankrig en særlig status som andenrangsborgere. Det må have været en chokerende oplevelse for landets jøder at opleve, at de blev udskilt fra resten af befolkningen på grund af deres religion og ,race“. Tværs over deres identitetskort fik de stemplet betegnelsen jøde, og de skulle gå med en stor gul davidsstjerne på brystet, hvor betegnelsen „Juif“ var trykt (Bruttmann 2006).

I 1941 begyndte besættelsesmagten bistået af det franske politi at arrestere jøder, sende dem til opsamlingslejre og dernæst til udslettelseslejre. La rafle $d u$ Vel d'Hiv er betegnelsen på den mest kendte og frygtelige razzia i Paris. Den fandt sted den 16. og 17. juli 1942 og er opkaldt efter vintercykelbanen Le Velodrome d'Hiver, hvor 8.000 af de arresterede jøder - kvinder, børn, oldinge og mænd, blev interneret under forfærdelige forhold, inden de blev ført videre til andre lejre og til slut sendt af sted til Auschwitz.

Ganske vist blev omkring 76.000 jøder deporteret fra Frankrig, heraf var 11.000 børn, og kun 2.500 af alle de deporterede overlevede, men det var kun en fjerdedel af alle jøder i Frankrig. Det vil sige, at tre fjerdedele af jøderne ikke blev deporteret, men at de overlevede i Frankrig eller som flygtninge i andre lande. Nogle blev skjult af portnerkonen eller naboer i ejendommen, andre tog ophold $i$ 
landsbyer hos bønder eller på kroer, og selv om alle i landsbyen vidste, at de var jøder, undlod de at angive dem (Kaspi 1991; Marrus \& Paxton 1981; Poznanski 1994; Zuccotti 1993).

Allerede ved befrielsen begyndte kampen om historien: Hvad skulle der herske tavshed om, og hvad skulle der tales om? General Charles de Gaulle havde i 1939 været medlem af regeringen, og han var rejst til England for at forhandle om, hvordan man kunne yde modstand mod besættelsesmagten. Den 18. juni 1940 havde han holdt en tale i engelsk radio, hvor han opfordrede til, at Frankrig fortsatte krigen. Han blev derpå af den nye regering betragtet som en landsforræder, mens han selv havde den opfattelse, at han i London repræsenterede det sande Frankrig. Da Frankrig og Tyskland havde underskrevet våbenstilstandsaftalen, blev de Gaulle anerkendt af England som leder af det frie Frankrig, og fra sin base i London begyndte han at opbygge sin hær.

Allerede inden befrielsen valgte modstandsbevægelsen de Gaulle som regeringsleder af det frie Frankrig, og i juni 1944 blev han leder af Den Franske Republiks midlertidige regering. Først den 23. oktober blev hans regering anerkendt af stormagterne, men det var takket være de Gaulle og hans frie franske hær, at Frankrig blev indbudt til sejrherrernes forhandlinger, efter at Nazityskland havde kapituleret den 8. maj 1945.

Inden Paris blev befriet, erklærede den Den Franske Republiks midlertidige regering ved et dekret Vichy-styrets beslutninger for ugyldige. Alle de love, som dette styre havde vedtaget, faldt dermed bort, heriblandt alle særlovene for jøder. Med et pennestrøg blev jøder i Frankrig således atter indlemmet i republikken, og med denne gestus viste de Gaulle, at Vichy-styret skulle opfattes som en parentes i republikkens historie. Hvad Vichy-styret havde repræsenteret, var ikke det sande Frankrig, men en selvbestaltet magt, L'État français.

Det sande Frankrig havde derimod været i London hos de Gaulle. Det viste sig også ved, at han, da han fra balkonen på rådhuset i Paris den 25. august 1944 talte til sine landsmænd, nægtede at udråbe republikken, for i hans øjne var republikken aldrig ophørt med at eksistere. Hermed blev der samtidig skabt en myte om det kæmpende Frankrig, om la Résistance, og en opfattelse af, at stort set hele landet havde været med i modstandsbevægelsen bortset fra de få skiderikker, der havde været en del af Vichy-styret eller støttet det (Rousso 2001).

\section{Glemsel og erindring}

I de knap 70 år, der er gået siden befrielsen, har mindekulturen i Frankrig ændret fokus. Årene umiddelbart efter befrielsen var kendetegnet ved, at det var det kæmpende Frankrig, som skulle mindes. Det var modstandsfolk, der blev rejst 
mindesmærker for, og når det jødiske trossamfund opsatte mindeplader i synagogerne, var det de jødiske modstandshelte, der blev mindet.

Når ,de deporterede“ blev omtalt, var det som en samlet gruppe, og jøderne blev betragtet som en del af de hundredtusinder af mennesker, der i øvrigt var blevet deporteret fra Frankrig, fordi de var kommunister eller modstandsfolk. For den generation af jøder, som selv havde været omfattet af Vichy-styrets jødeforfølgelse og udelukkelse, var det vigtigste, at de atter blev budt indenfor i republikkens nationale fællesskab. For dem var det netop en befrielse ikke længere at blive udgrænset som en gruppe for sig (Wieviorka 1992).

I efterkrigsårene var der dog én bemærkelsesværdig undtagelse fra dette med udelukkende at mindes det kæmpende Frankrig og dette ikke at give jøder særstatus. Det var oprettelsen af et mindesmærke for den jødiske martyr, som forretningsmanden Isaac Schneersohn var initiativtager til. Han var i 1920 flygtet fra Rusland til Frankrig, og under den tyske besættelse havde han skjult sig i den sydvestlige del af Frankrig. I april 1943 samlede han omkring 40 repræsentanter for de vigtigste jødiske organisationer. De stiftede Centre de Documentation Juive Contemporaine, CDJC, der havde til hensigt at indsamle alle former for dokumenter, der ville give jøder mulighed for at indtage deres plads i det franske samfund, når krigen var forbi. Meget af det blev brugt som beviser under Nürnberg-processen. Centeret påtog sig også at udgive bøger og kildesamlinger i årene efter krigen og var på den måde med til at bryde tavsheden og huske, minde og advare.

I 1950 ønskede Schneersohn at forene sit dokumentationscenter, arkiv og bibliotek med en udstilling, en konferencesal og en mindehal for den ukendte jødiske martyr. Efter hans opfattelse blev mindet bedre overleveret ved hjælp af ceremonier end gennem krøniker. Inspirationen hentede han i den måde, man i Frankrig mindedes de faldne soldater under Første Verdenskrig på, hvor hver en by og landsby havde oprettet et mindesmærke med de faldnes navne indhugget. Monumentet over alle monumenter var dog graven for Den Ukendte Soldat. I 1920 var liget af en ukendt soldat blevet gravsat under Triumfbuen i Paris som symbolet på alle franske soldater dræbt under Første Verdenskrig. Schneersohn ville, at der i Paris skulle være et lignende gravsted som symbolet på alle de seks millioner europæiske jøder, der var blevet dræbt under Anden Verdenskrig.

Her fem år efter krigens afslutning var der en vis bitterhed hos mange af de overlevende jøder over, at deres katastrofe syntes at gå i glemmebogen. Den kolde krig var sat ind, de allierede ønskede at inddrage Vesttyskland i den frie verden, og for at det kunne lykkes, gled krigens skændsler i baggrunden.

Knap var idéen om Tombeau du martyr juif inconnu blevet undfanget, førend den mødte modstand. Zionister syntes, at et sådant mindesmærke skulle opføres i 
Israel. De jøder, som gik ind for assimilation, syntes, at dette at fremhæve jødisk lidelse ville hindre integration i det franske samfund. Traditionelle jøder henviste til, at det brød med den jødiske form for sorg og erindring, og at det jødiske bud om aldrig at glemme skulle efterkommes med skriften og ikke med bygninger. Andre opfattede det som en slags omvendt racisme, at man ville hædre krigens jødiske ofre, men ikke dens ofre fra andre trossamfund.

Endvidere var der kritik mod selve stedet. Hvorfor netop Paris? Burde mindesmærket ikke stå lige midt i Tyskland, så gerningsmændene hele tiden kunne blive mindet om deres udåd? Eller måske skulle det stå i Østeuropa og minde om den verden, som nu var udslettet. Udgifterne til monumentet blev også kritiseret, for her i efterkrigstiden, hvor så mange led nød, var der rigeligt at bruge sine penge til.

Alligevel støttede mange prominente mennesker idéen, og i løbet af foråret 1951 blev der nedsat internationale komitéer med de fremmeste mænd og kvinder. Niels Bohr var en af de første, som blev opfordret til at indtræde, og efter anmodning sendte han følgende udtalelse til Paris: „Et sådant mindesmærke vil for kommende slægter stå som udtryk for samtidens deltagelse i sorgen over den skæbne, som de mange medmennesker måtte lide, og blive en stadig påmindelse om det afgrundsdyb, der til enhver tid kan åbne sig for vor fod, om vi ikke sammen står vagt for at værne om de idealer, der ligger til grund for menneskehedens fælles stræben“ (Niels Bohr arkivet, Niels Bohr Institutet). Mindesmærket blev indviet i 1956, og i 2005 blev det sammen med dokumentationscenteret til institutionen Mémorial de la Shoah (Wieviorka 1987, 2004).

I disse efterkrigsår var der fuldstændig tavshed omkring Vichy-styrets ansvar for jødedeportationerne. Når jødiske foreninger på begravelsespladser i disse år rejste mindesmærker for deres deporterede medlemmer, blev det indhugget i stenen, at de havde været ofre for ,nazistisk barbari“. Gerningsmændene blev udpeget som „,nazister“ og ikke som „tyskere“. Det var således en ideologi, som blev gjort ansvarlig og ikke en hel nation.

\section{Pligten til at huske}

Denne tavshed vedrørende Vichy-styrets ansvar blev brudt i løbet af 1990'erne. De Gaulle havde som sagt allerede ved befrielsen sat en parentes rundt om ,den franske stat" og understreget, at republikken havde levet videre sammen med ham og modstandsbevægelsen. De efterfølgende præsidenter havde ligeledes været tavse som graven, og da mange franskmænd havde været indblandet i styret, fandt alle det bedst at holde mund. Frankrig var ramt af det, som historikeren Henry Rousso i 1987 kaldte Vichy-syndromet (Rousso 1987). 
I 1992 var det 50-året for de første deportationer af jøder fra Frankrig, og det gav anledning til utallige mindehøjtideligheder i det jødiske samfund. I 1942 havde den såkaldte Rafle du Vel d'Hiv som nævnt været den mest omfattende razzia. Siden befrielsen havde der været afholdt mindeceremonier foran cykelbanen, som i 1950'erne fortsatte med at danne rammen for festlige seksdagesløb. I 1959 blev den revet ned efter en brand, og den årlige mindehøjtidelighed blev afholdt på det sted, hvor cykelbanen havde stået.

Comité Vel d'Hiv '42 blev stiftet i 1992 og anmodede præsidenten, François Mitterrand, om at fremsætte en undskyldning på den franske stats vegne. Det var første gang, at en præsident blev bedt om at tage ansvaret for Vichy-styrets jødeforfølgelse, men Mitterrand svarede helt i de Gaulles ånd, at republikken ikke kunne gøres ansvarlig for, hvad „,den franske stat“ under Vichy have gjort. Det affødte en hidsig debat i medierne, men det endte med, at Mitterrand som den første præsident nogensinde mødte op den 16. juli til mindehøjtidelighed for Rafle du Vel d'Hiv. Uden et ord lagde han en blomsterbuket på stedet.

Komitéen henvendte sig nu til parlamentet og anmodede politikerne om, at de gjorde den 16. juli til en national mindedag. Året efter udstedte Mitterrand en forordning, der indstiftede en national mindedag for de racistiske og antisemitiske forfølgelser, som var blevet begået under det midlertidige styre for den franske stat fra 1940 til 1944. Det blev endvidere besluttet at opføre forskellige monumenter rundt om i landet, og på Place des Martyrs Juifs du Vélodrome d'Hiver i 15. arrondissement blev et mindesmærke opført. Det skal erindre om alle jøder, der blev deporteret fra Frankrig, og ikke kun om dem, som blev arresteret den 16. juli 1942 .

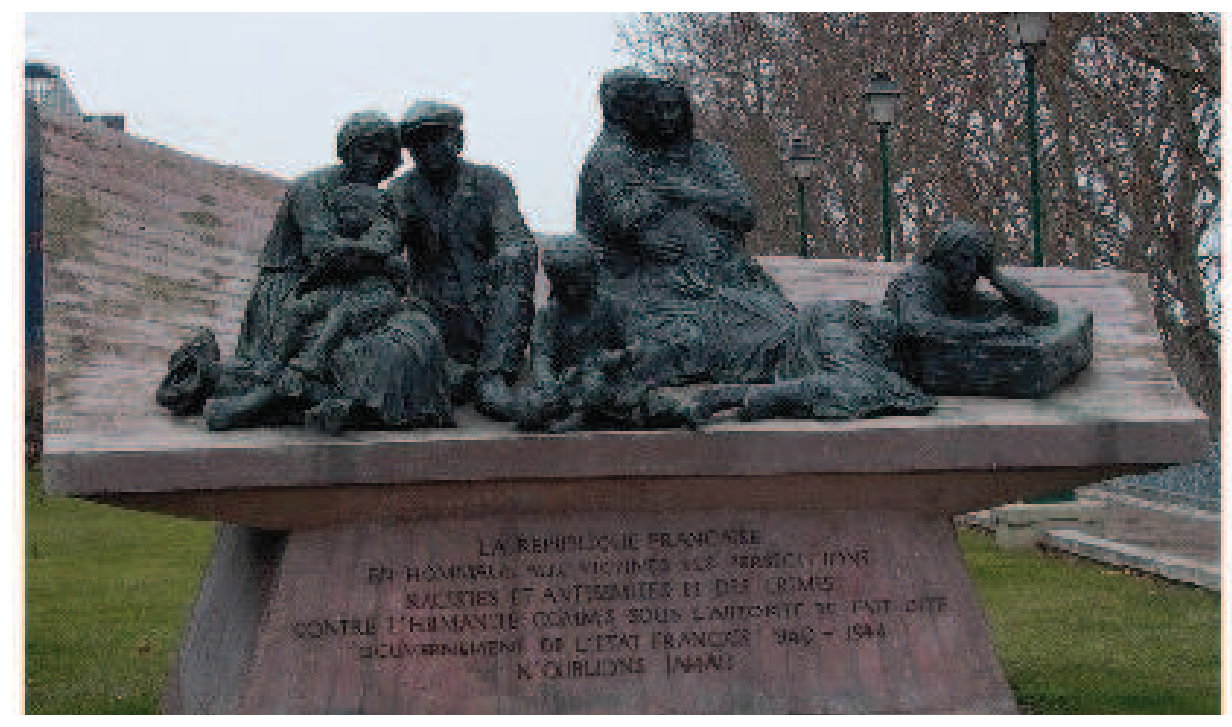


På soklen af monumentet er denne tekst indhugget: „,Den franske republik ærer ofrene for de racistiske og antisemitiske forfølgelser og forbrydelser mod menneskeheden begået under den såkaldte 'regering for den franske stat' 1940-1944. Lad os aldrig glemme det" (Barcellini 1995:90-7; Wieviorka 1997:288-92; Wiedmer 1999:38-57; Carrier 2005). Den 17. juli 1994 blev det indviet af Mitterand.

Det var her ved dette mindesmærke, at en fransk præsident for første gang udtalte offentligt, at det var skændigt, hvad Vichy-styret havde gjort mod landets jøder. Jacques Chirac, som da var den nyvalgte præsident, talte den 16. juli 1995 ved denne nye nationale mindedag (Wieviorka 1997:293-4). Chirac er født i 1932 og kunne derfor ikke have været indblandet i noget som helst under Anden Verdenskrig. Han har som den første franske præsident siden befrielsen nåden ved at være født for sent.

Chirac begyndte sin tale med at sige, at i en nations liv er der øjeblikke, som sårer erindringen og den idé, man gør sig om sit land. Disse øjeblikke er vanskelige at fremmane, fordi man ikke kan finde de rette ord til at genkalde sig rædslen eller for at udtrykke den sorg, som de mennesker, der har gennemlevet tragedien, har følt. De er også vanskelige at fremmane, „fordi disse sorte timer for altid tilsmudser vor historie og er en hån mod vor fortid og vore traditioner“" (Internetkilde 1). Chirac fortsatte: „Ja, besættelsesmagtens forbryderiske vanvid blev bistået af franskmænd, af den franske stat.“ Denne sætning, som oven i købet begynder med et ja, altså med en indrømmelse, siger højt og tydeligt, at den franske regering samarbejdede med besættelsesmagten.

Derpå beskrev Chirac, hvad der var sket den 16. juli 1942, da franske politibetjente adlød nazisternes ordre, de rædselsvækkende scener, som udspillede sig, da kvinder, børn og gamle, hvoraf flere var veteraner fra Første Verdenskrig, blev smidt ind i parisiske busser og i politiets salatfade. For alle disse arresterede mennesker begyndte nu en rejse mod helvede, og hvor mange har mon følt sig forrådt? ,Frankrig, landet for oplysningen og menneskerettighederne, modtagelsesog tilflugtsland, Frankrig, udførte den dag det ubodelige. Idet det svigtede sit ord, udleverede Frankrig de mennesker, som det havde under sin beskyttelse, til deres bødler. Over for dem bevarer vi en uforældelig gæld.“

Men Chirac ville også minde om, at netop i 1942 sluttede flere franskmænd sig til modstandskampen, utallige jøder blev skjult af franskmænd, som risikerede deres eget liv, og de frie franske tropper sejrede i Libyen. Der var ganske vist blevet begået fejl. ,Men der er også et Frankrig, en særlig idé om Frankrig, retsindig, ædel, trofast mod sine traditioner, mod sin ånd. Dette Frankrig var aldrig i Vichy. "Hermed fortsatte Chirac den opfattelse, som de Gaulle havde påbegyndt, og som Mitterrand havde videreført: Vichy var ikke det rigtige Frankrig. Chirac afsluttede talen med at minde om de demokratiske principper, som alle måtte kæmpe for (Internetkilde 1 og 2). 
Denne meget smukke og gribende tale fra 1995 er siden blevet betragtet som et vendepunkt i den tavshed, der havde hersket i Frankrig vedrørende Vichy-styret. Lige siden befrielsen var det officielle Frankrig krøbet uden om denne skændsel ved at fastholde de Gaulles parentes, men nu satte det nærmest gang i en lavine af mindekultur. Jacques Chirac talte siden ved utallige indvielser af mindesmærker og til mindehøjtideligheder, og hver gang brød han tavsheden, men huskede også at erindre om det heltemodige Frankrig.

Det bestod ikke blot af modstandskæmpere, men også af ganske almindelige ikke-jødiske franskmænd, som hjalp deres jødiske medborgere i nøden. Deres heltedåd blev ligeledes glemt $i$ årene efter befrielsen, fordi den ikke var blevet skabt $\mathrm{i}$ kamp. Men de havde vovet livet for at skjule og hjælpe jøder, og de kunne selv være blevet deporteret og dræbt, hvis de var blevet opdaget. Sådanne ikkejøder, som reddede jøder fra Holocaust, blev allerede i 1953 erindret af den nye stat Israel. Her blev institutionen Yad Vashem dannet for at mindes ofrene for Holocaust og for at sikre, at mindekulturen ikke udelukkende blev varetaget $i$ Paris af CDJC. Som noget af det første sørgede Yad Vashem for, at disse ikkejøder blev hædret med titlen Righteous among the Nations (retfærdige blandt nationerne). På fransk kaldes de Les Justes parmi les Nations, og i kølvandet på erindringen om ofrene for la Shoah er opmærksomheden også blevet rettet mod dem. Det kulminerede i 2007, da præsident Chirac holdt en stor mindeceremoni i Panthéon i Paris for de 2.725 mennesker, Yad Vashem har udvalgt som Justes de France (Gensburger 2010).

Det er dog især de jødiske ofre, som i den seneste snes år er blevet trukket frem fra glemslen. Siden 2002 er der rundt om i Paris blevet opsat mindetavler på skoler for at mindes de deporterede skolebørn. På begravelsespladsen uden for byen kan man endnu se de små mindesten, nu angrebet af skimmelsvamp, som lige efter befrielsen erindrede de deporterede familiemedlemmer, der var blevet ofre for de ,nazistiske bødler“.

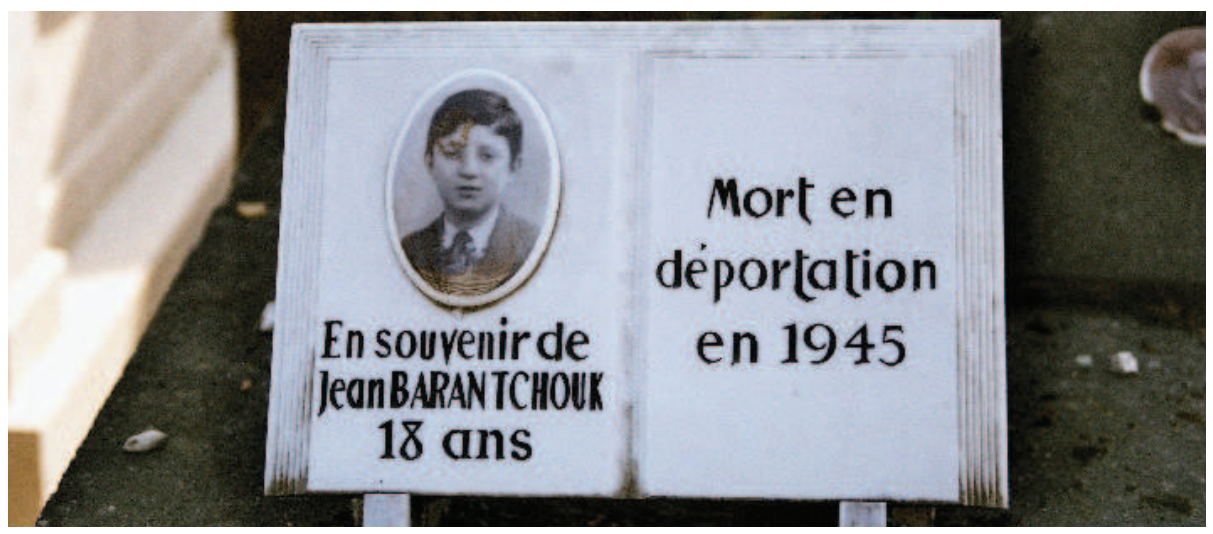


Helt anderledes bliver deportationen husket på de splinternye, blanke og sorte mindetavler, som med klare guldbogstaver forkynder følgende: „Fra 1942 til 1944 blev mere end 11.000 børn deporteret fra Frankrig af nazisterne, med aktiv medvirken af den franske regering i Vichy, og myrdet i dødslejrene, fordi de var født som jøder.“ I højre hjørne var dette påbud indprentet: „Ne les oublions jamais“, lad os aldrig glemme dem.

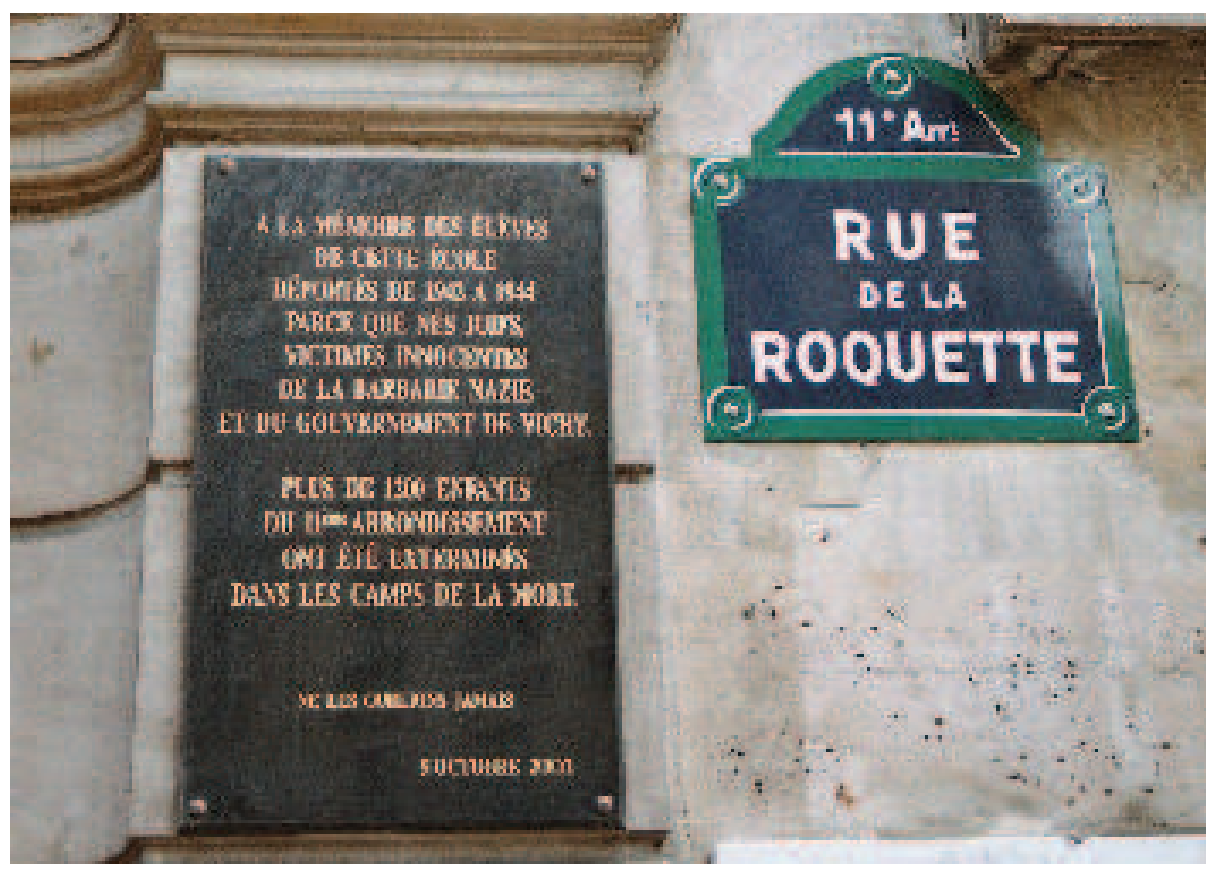

Bedre sent end aldrig kunne man så sandelig sige, og modsætningen mellem de forsigtigt udtrykte og nu falmede mindesten på begravelsespladsen uden for byen og så de næsten aggressivt konstaterende nye mindetavler inde i byen er påfaldende. Erindringen om jødeforfølgelsen har således ændret sig fra det spagfærdige til det konfronterende.

Det er ofte efterkommere af de franske jøder, som var omfattet af Vichy-styrets forfølgelse, der engagerer sig i denne mindekultur. For dem drejer det sig vedvarende om at tvinge Frankrig til gennem mindeceremonier at tage ansvar for sine gerninger. Men det er gerninger, denne generation ikke var truet af, og som de nulevende politikere ikke havde ansvaret for. Mindesmærker og mindehøjtideligheder er ikke kun håndgribelige eksempler på, hvad det er for en del af fortiden, det officielle Frankrig mindes. De er også et udtryk for kampen om historien og kampen om fortolkning af fortiden, for kampen mellem tavshed og tale (Lalieu 2001; Blanchard \&Veyrat-Masson 2008; Michel 2010). 
Men hvorfor er efterkommerne så opslugt af den døde fortid? Det har den franske historiker Annette Wieviorka forsøgt at give et svar på i sine mange arbejder om den jødiske mindekultur i Frankrig. „Kravet om en erindring udtrykker i sidste ende et identitetskrav for jøder uden religion, og det sker i Frankrig, såvel som i Israel og i USA“ (Wieviorka 1993:713-4). Nu kan sekulære jøder ikke længere finde deres identitet i den jødiske arbejderbevægelse, for „masserne“ findes ikke længere, og jiddisch er ikke mere et sprog, der forener. I stedet kommer krigen til at spille en rolle som en oprindelsesmyte for deres jødiskhed, og alle disse mindeceremonier og mindehøjtideligheder for krigens ofre er på vej til at skabe en ny borgerlig religion for sekulære jøder. Men, spørger Annette Wieviorka, mon ikke de bare på deres helt egen måde giver udtryk for det, som andre franskmænd giver udtryk for på andre måder?: en frygt for fremtiden og et fravær af et forehavende (Wieviorka 1993:713-4; 1997:295-6).

Hele denne opslugthed af Shoah, af Holocaust, som har grebet mange mennesker verden over, jøder som ikke-jøder, er vokset frem med stor styrke lige efter den kolde krigs ophør. Nu er modstandskampen gledet i baggrunden, og ofret, vidnet, er kommet i forgrunden (Wieviorka 1998). I løbet af 1990'erne og især i det nye årtusinde er der blevet oprettet museer for Holocaust, den 27. januar, den dato hvor Auschwitz i 1945 blev befriet, er blevet udnævnt til international mindedag for Holocaust, der oprettes centre for forskning i Holocaust, og undervisningsministre underskriver erklæringer om, at der skal undervises i Holocaust. Det vil ingen ende tage, og i takt med at de sidste Holocaust-overlevere dør af alderdom, bliver der gjort alt for, at viden om Holocaust ikke tillige skal dø.

Men som titlen på en konference i Paris i 2009 spurgte: „I denne erindringens tidsalder, hvilken fremtid har glemslen så?“ (Internetkilde 3). Spørgsmålet er vel, hvor længe vi skal mindes, hvad det er, vi skal mindes, og med hvilket formål. Min mors tavshed om sin baggrund står i stærk kontrast til denne vedvarende tale, og den understreger dilemmaet om private menneskers ret til tavshed og glemsel og staters pligt til at huske og mindes.

Søgeord: familiehemmelighed, erindringspolitik, mindesmærker, Holocaust, Frankrig, jødisk indvandring

\footnotetext{
Litteratur

Barcellini, Serge

1995 Sur deux journées nationales commémorant la déportation et les persécutions des „Années noires“. Vingtième Siècle: Revue d'histoire 45:76-98.

Blanchard, Pascal og Veyrat-Masson, Isabelle (red.)

2008 Les guerres de mémoires: La France et son histoire, enjeux politiques, controverses historiques, stratégies médiatiques. Paris: Editions La Découverte.
} 
Bruttmann, Tal

2006 Au bureau des affaires juives: L'administration française et l'application de la législation antisémite (1940-1944). Paris: La Découverte.

Carrier, Peter

2005 "Paris: the Vél' d'Hiv' and the Promise of National Reconcilitation 1992-97". I:

P. Carrier: Holocaust Monuments and National Memory Cultures in France and

Germany since 1989. New York: Berghan Books.

Gensburger, Sarah

2010 Les Justes de France: Politiques publiques de la mémoire. Paris: Presses de

Sciences Po.

Kaspi, André

1991/1997 Les Juifs pendant l’Occupation. Paris: Seuil.

Lalieu, Olivier

2001 L'invention du „Devoir de mémoire“. Vingtième Siècle: Revue d'histoire 69:83-94.

Lützen, Karin

2009 Mors hemmelighed. På sporet af en jødisk indvandrerhistorie.

København: Gyldendal.

Marrus, Michael R. \& Robert O. Paxton

1981/1995 Vichy France and the Jews. Stanford: Stanford U.P.

Michel, Johann

2010 Gouverner les mémoires - Les politiques mémorielles en France.

Paris: Presses Universitaires de France - PUF.

Poznanski, Renée

1994/1997 Les Juifs en France pendant la Seconde Guerre mondiale. Paris: Hachette.

Rousso, Henry

1987 Le Syndrome de Vichy de 1944 à nos jours. Paris: Seuil.

Rousso, Henry

2001 Vichy: L'événement, la mémoire, l'histoire. Paris: Gallimard.

Safran, William

1991 State, Nation, National Identity, and Citizenship: France as a Test Case. International Political Science Review 12(3):219-38.

1997 Citizenship and Nationality in Democratic Systems: Approaches to Defining and Acquiring Membership in the Political Community. International Political Science Review 18(3):313-35.

Smart, Carol

2011 Families, Secrets and Memories. Sociology 45(4):539-53.

Wiedmer, Caroline

1999 The Claims of Memory: Representations of the Holocaust in Contemporary Germany and France. Ithaca: Cornell U.P.

Wieviorka, Annette

1987 Un lieu de Mémoire et d'Historie: Le Mémorial du Martyr juif inconnu. I: Les juifs entre la mémoire et l'oubli, særnummer af Revue de l'Université de Bruxelles 1-2:107-32. 
Déportation et génocide: Entre la mémoire et l'oubli. Paris: Plon.

1997 Deportation and Memory: Official History and the Rewriting of World War II.

I: A.H. Rosenfeld (red.): Thinking about the Holocaust After Half a Century.

Bloomington: Indiana U.P.

1998 L'ère du témoin. Paris: Hachette.

2004 Du Centre de documentation juive contemporaine au Mémorial de la Shoah. Revue d'historie de la Shoah 181:11-36.

Winock, Michel

2004 La France et les juifs de 1789 à nos jours. Paris: Seuil.

Zuccotti, Susan

1993/1999 The Holocaust, the French, and the Jews. Lincoln: Nebraska U.P.

\section{Internetkilder}

1. http://fr.wikisource.org/wiki/Discours_prononc\%C3\%A9 lors

des comm $\%$ C3\%A9morations de la Rafle du Vel\%E2\%80\%99

$\mathrm{d} \% \overline{\mathrm{E}} 2 \% 80 \% 99 \mathrm{Hiv} \% \mathrm{E} 2 \% 80 \% \overline{9}$.

2.

http://www.ina.fr/fresques/jalons/fiche-media/InaEdu01248/discours-de-jacqueschirac-sur-la-responsabilite-de-vichy-dans-la-deportation-1995.html. Denne kilde er en video af nyhedsudsendelsen med brudstykker af ceremonien og Chiracs tale.

3. http://www.centrealbertobenveniste.org/?page_id=1609. 
